\title{
$\mathfrak{J} \mathfrak{R} \mathfrak{a} \mathfrak{n}$
}

\section{fämmtlidhe SBerfe.}

3 weiter $\mathfrak{B a n b}$.

$$
\begin{aligned}
& \text { 象exin, } \\
& b \text { e } \mathfrak{i} \text { (S. } \mathfrak{R} \text { e } \mathfrak{i} \text { m }
\end{aligned}
$$

1840. 
